\title{
Solvothermal synthesis and electrochemical charge storage assessment of $\mathrm{Mn}_{3} \mathrm{~N}_{2}$
}

S. Imran U. Shah, Andrew L. Hector, * Xianji Li and John R. Owen

Chemistry, University of Southampton, Highfield, Southampton SO17 1BJ, UK.

A.L.Hector@soton.ac.uk

$\eta-\mathrm{Mn}_{3} \mathrm{~N}_{2}$ is produced using solvothermal reactions between $\mathrm{MnCl}_{2}$ and $\mathrm{LiNH}_{2}$ in benzene. At $350{ }^{\circ} \mathrm{C}$ nanocapsule structures are obtained, whereas at higher temperatures samples consisted of isotropic nanoparticulates. In aqueous $\mathrm{KOH}$ solution capacitances of up to $300 \mathrm{~F} \mathrm{~g}^{-1}$ ( $2 \mathrm{mV} \mathrm{s}^{-1}$, potential window 0.3 to $-0.6 \mathrm{~V}$ vs $\mathrm{Hg} / \mathrm{HgO})$, but capacitance fell to relatively low values on cycling. In lithium cells a reversible first cycle capacity of $600 \mathrm{~mA} \mathrm{~h} \mathrm{~g}^{-1}$ was obtained, and this decayed to $340 \mathrm{~mA} \mathrm{~h} \mathrm{~g}^{-1}$ after 50 cycles. In sodium cells a reversible first cycle capacity of $156 \mathrm{~mA} \mathrm{~h} \mathrm{~g}^{-1}$ was obtained and was maintained well on cycling (127 $\mathrm{mA} \mathrm{h} \mathrm{g}^{-1}$ in the $50^{\text {th }}$ cycle).

\section{Introduction}

Four major phases exist in the $\mathrm{Mn}-\mathrm{N}$ binary system. $\varepsilon-M n_{4} \mathrm{~N}^{1}$ is an anti-perovskite consisting of face centred cubic manganese atoms with nitrogen in $1 / 4$ of the octahedral holes. The defect NiAs-type $\zeta$ $\mathrm{Mn}_{2} \mathrm{~N}$ phase has a range of nitrogen contents typically from $\mathrm{MnN}_{0.42}{ }^{2}$ to $\mathrm{Mn}_{2} \mathrm{~N}_{1.08 .}{ }^{3}$ with nitrogen occupancy varying according to the composition. $\eta-\mathrm{Mn}_{3} \mathrm{~N}_{2}{ }^{4,5}$ and the $\theta$-phases $\mathrm{MnN}^{6}$ and $\mathrm{Mn}_{6} \mathrm{~N}_{5}{ }^{7}$ are tetragonally distorted rocksalt-type structures with nitrogen vacancies. Much of the previous interest in manganese nitrides has focussed on their magnetic properties $-M n N, M n_{3} N_{2}$ and $M n_{2} N$ are antiferromagnetic, while $\mathrm{Mn}_{4} \mathrm{~N}$ is ferromagnetic. ${ }^{6,8}$

Metal nitrides are a current research focus as electrode materials for electrochemical capacitors due to a number of studies that have shown useful capacities on TiN, VN and MoN. . $^{9} 10,11,12$ The current redox capacitor material of choice is $\mathrm{RuO}_{2}$, which can deliver capacities of around $720 \mathrm{~F} \mathrm{~g}^{-1}$ but is too costly and toxic for widespread use. ${ }^{13} \mathrm{~A}$ number of other oxides have also been used, but the current interest in nitrides comes from the possibility of producing materials with a high electronic conductivity nitride core and an oxide coating with a high surface area. Manganese dioxide is one promising replacement for $\mathrm{RuO}_{2}$. It undergoes pseudocapacitive reactions during surface adsorption and intercalation into the bulk of the electrode: ${ }^{14}$

$$
\mathrm{MnO}_{2}+\mathrm{Cat}^{+}+\mathrm{e}^{-} \leftrightarrow \mathrm{CatMnO}_{2}
$$

Where $\mathrm{Cat}^{+}$is the electrolyte cation (e.g. $\mathrm{H}^{+}$under aqueous conditions or $\mathrm{Li}^{+}$with an organic electrolyte) and the manganese cycles between the +3 and +4 oxidation states. $\mathrm{MnO}_{2}$ can deliver capacitances of $\sim 240 \mathrm{~F} \mathrm{~g}^{-1}$, although this is over a relatively narrow potential range and is subject to some fading during cycling. ${ }^{15}$ An oxide surface can develop during cycling of metal nitride electrodes ${ }^{11}$ and this prompted our interest in making nanoparticulate manganese nitrides. 
There is also a developing literature in the use of metal nitrides as conversion electrodes ${ }^{16}$ in lithium and sodium batteries, where the metal nitride is reduced to metal and lithium nitride. In lithium cells capacities during cycling as high as $\sim 1200 \mathrm{~mA} \mathrm{~h} \mathrm{~g}^{-1}$ have been observed (with $\mathrm{CrN}^{17}$ ), and useful capacity has been observed with $\mathrm{Mn}_{4} \mathrm{~N},{ }^{18} \mathrm{Fe}_{3} \mathrm{~N},{ }^{19} \mathrm{CoN},{ }^{20} \mathrm{Co}_{3} \mathrm{~N}_{1}{ }^{19} \mathrm{Ni}_{3} \mathrm{~N}^{21}$ and $\mathrm{Cu}_{3} \mathrm{~N} .{ }^{22}$ We have recently reported the use of $\mathrm{Ni}_{3} \mathrm{~N}^{23}$ and $\mathrm{Cu}_{3} \mathrm{~N}^{24}$ as sodium battery negative electrodes, which deliver lower capacities of $\sim 100 \mathrm{~mA} \mathrm{~h} \mathrm{~g}^{-1}$ but provide better stable cycling behaviour compared with many other sodium battery negative electrode materials. ${ }^{25} \mathrm{Mn}_{3} \mathrm{~N}_{2}$ films prepared by magnetron sputtering with a thickness of $\sim 350 \mathrm{~nm}$ have recently been reported to exhibit capacities of up to $579 \mathrm{~mA} \mathrm{~h} \mathrm{~g}^{-1}$ in the $0-2.5 \mathrm{~V}$ range ( $v s \mathrm{Li}$ ) in lithium half cells, and retained $463 \mathrm{~mA} \mathrm{~h} \mathrm{~g}{ }^{-1}$ of this capacity on the $110^{\text {th }}$ cycle. ${ }^{26}$ This material has not previously been examined $v s$ lithium in more conventional composite electrodes, or vs sodium. $\mathrm{MnO}_{2}$ and other manganese oxides are common positive electrode materials in primary and Li-ion batteries, taking advantage of their low cost and toxicity, high capacities and in some cases high potentials. ${ }^{27}$

Nitridation of manganese powder with ammonia at $600{ }^{\circ} \mathrm{C}$ yields $\mathrm{Mn}_{2} \mathrm{~N},{ }^{28}$ whereas nanocrystalline $\mathrm{Mn}_{4} \mathrm{~N}$ and $\mathrm{Mn}_{2} \mathrm{~N}$ may be prepared by mechanical alloying and nitridation of $\mathrm{Mn}$ powders ${ }^{29}$ and $\mathrm{Mn}_{3} \mathrm{~N}_{2}$ has been produced by using $\mathrm{NaN}_{3}$ to develop nitrogen pressure in an autoclave and nitriding manganese powder at $750{ }^{\circ} \mathrm{C} .{ }^{7} \mathrm{MnN}$ was first prepared as a single phase by $\mathrm{DC}$ reactive sputtering in an $\mathrm{Ar}-\mathrm{N}_{2}$ mixture. ${ }^{6} \mathrm{Mn}_{4} \mathrm{~N}$ has been obtained from the solid state metathesis reactions of $\mathrm{MnCl}_{2}$ with $\mathrm{NaN}_{3}{ }^{30}$ or $\mathrm{Ca}_{3} \mathrm{~N}_{2},{ }^{31}$ and from $\mathrm{Mnl}_{2}$ with $\mathrm{Li}_{3} \mathrm{~N}^{32}$ and similar exchange reactions have been used to make crystals of $\mathrm{Mn}_{6} \mathrm{~N}_{5}$ and $\mathrm{Mn}_{3} \mathrm{~N}_{2}$ from $\mathrm{Mnl}_{2}$ and $\mathrm{NaNH}_{2}$ in ammonia at $6 \mathrm{KBar}$ and 400 to $600{ }^{\circ} \mathrm{C} .{ }^{33}$ $\mathrm{Mn}_{3} \mathrm{~N}_{2}$ has also been prepared by solid state reaction of $\mathrm{MnCl}_{2}$ with $\mathrm{LiNH}_{2}$ followed by pyrolysis of the product in ammonia. ${ }^{34}$ We have a long-standing interest in producing metal nitrides using solvothermal reactions using reactions of metal halides with ammonia or lithium amide, ${ }^{35,36}$ including to make a variety of nanorod and nanotube structures. An important aspect of these reactions is that heat absorption by the solvent can be effective in targeting small crystallite materials. Hence we were interested in applying these methods to the manganese nitride system. The one previous solvothermal study of manganese nitride synthesis used $\mathrm{NaN}_{3}$ as the nitrogen source and required temperatures to be raised extremely slowly to avoid self-propagating reactions. ${ }^{37} \mathrm{MnCl}_{2}$ and $\mathrm{NaN}_{3}$ were ground together and heated in toluene to $290{ }^{\circ} \mathrm{C}$ over a period of 3 days, then maintained for a further 3 days. This reaction produced $\mathrm{MnN}$ with stirred powders or a mixture of $\mathrm{Mn}_{3} \mathrm{~N}_{2}$ and $\mathrm{Mn}_{4} \mathrm{~N}$ in the solid mixture was pelletised, presumably due to higher temperatures inside the pellets.

In our current study we report synthesis of nanocrystalline $\mathrm{Mn}_{3} \mathrm{~N}_{2}$ through a solvothermal reaction between $\mathrm{MnCl}_{2}$ and $\mathrm{LiNH}_{2}$. We also assess its capability as an electrode material for aqueous supercapacitor applications, and as a negative electrode for sodium and lithium batteries.

\section{Experimental}

All procedures were carried out under nitrogen in glove box or Schlenk apparatus. Solvothermal synthesis was carried out in a $75 \mathrm{~cm}^{3}$ Inconel autoclave (Parr $4740 \mathrm{CH}$ ) with silica liner and a pressure gauge arm. Typically $\mathrm{MnCl}_{2}\left(0.5 \mathrm{~g}, 4.0 \mathrm{mmol}\right.$, Sigma-Aldrich) and $\mathrm{LiNH}_{2}(0.19 \mathrm{~g}, 8 \mathrm{mmol}$, prepared from ${ }^{\mathrm{n}} \mathrm{BuLi}$ and ammonia as described previously ${ }^{36}$ ) were ground together and placed in the autoclave liner. Benzene $\left(20 \mathrm{~cm}^{3}\right.$, Fisher, dried by distillation from sodium) was added to the mixture and stirred with a spatula. The liner was sealed into the autoclave, which was heated at 350, 400, 
450, 500 or $550{ }^{\circ} \mathrm{C}$ for $15 \mathrm{~h}$ and then allowed to cool to room temperature. No pressure was registered in the autoclave during these reactions. The black sample and the solvent were transferred to a Schlenk tube and filtered, then the solid was washed with $3 \times 20 \mathrm{~cm}^{3}$ methanol (Fisher, distilled from sodium methoxide) to remove lithium salts. The black product ( $0.2 \mathrm{~g})$ was dried in vacuo and collected inside the glove box under nitrogen.

Thermogravimetric analyses (TGA) used a Mettler Toledo TGA/SDTA85le, samples were heated at $10^{\circ} \mathrm{C} \mathrm{min}^{-1}$ to $900{ }^{\circ} \mathrm{C}$ under flowing Ar at $65 \mathrm{~cm}^{3} \mathrm{~min}^{-1}$. Powder X-ray diffraction (PXD) patterns were collected in Bragg-Brentano geometry using a Siemens D5000 ( $\left.\mathrm{Cu}-\mathrm{K}_{\alpha 1}\right)$ and a sealed sample holder. Rietveld refinements used the GSAS ${ }^{38}$ package with standard structures taken from the ICSD $^{39}$ database. Crystallite sizes were extracted from the Lorentzian peak broadening using the method described in the GSAS manual ${ }^{40}$ and a silica standard to fix the Gaussian instrumental peak shape terms. Transmission electron microscopy (TEM) data were collected with a Hitachi H7000 (75 kV) or a Jeol JEM3010 (300 kV), with samples prepared by ultrasound dispersion into dry toluene and dropping onto carbon-coated $\mathrm{Cu}$ grids. Combustion analysis ( $\mathrm{C}, \mathrm{H}$ and $\mathrm{N}$ ) was outsourced to Medac Ltd and a $\mathrm{WO}_{3}$ oxidant was added to aid combustion. Infrared spectroscopy was performed using $\mathrm{Cs}$ disks on a Perkin Elmer Spectrum One FT-IR spectrometer. Raman spectra were collected on Renishaw 2000 microscope in the frequency range of 2000 to $400 \mathrm{~cm}^{-1}$, using He-Ne laser beam, 2.7 $\mathrm{mW}$ (power) with a wave length of $632.8 \mathrm{~nm}$.

Electrochemical testing used a Biologic SP150 or MPG potentiostat. Working electrodes were made by depositing an ink of the active material onto $50 \mu \mathrm{m}$ titanium (aqueous measurements, Advent research materials, $1.5 \times 2.5 \mathrm{~cm}$ pieces, $1.5 \times 1.5 \mathrm{~cm}$ area coated) or $5 \mu \mathrm{m}$ copper (Advent research materials, $1 \mathrm{~cm}$ disks) foil substrates. The composite inks were produced in air from manganese nitride (75 wt\%), acetylene black (20 wt\%, Shawinigan, Chevron Phillips Chemical Co) and polyvinylidene fluoride (PVDF, Sigma-Aldrich, $5 \mathrm{wt} \%$ ). PVDF was dissolved in cyclopentanone (SigmaAldrich, $1.5 \mathrm{~cm}^{3}$ per $100 \mathrm{mg}$ of composite) with $2 \mathrm{~h}$ stirring, then a ground mixture of $\mathrm{Mn}_{3} \mathrm{~N}_{2}$ and acetylene black was added and the mixture stirred overnight. After dropping the ink onto the foil and allowing to dry, it was further dried overnight under vacuum at $120^{\circ} \mathrm{C}$, and the amount of active material on an electrode ( $1.6 \mathrm{mg}$ ) was calculated by mass difference.

Aqueous electrochemical experiments used three electrode cells with a $\mathrm{Hg} / \mathrm{HgO}$ reference electrode filled with $1 \mathrm{~mol} \mathrm{dm}^{-3}$ aqueous $\mathrm{KOH}$ and a high surface area platinum gauze counter electrode. Electrochemical cells were assembled with $20 \mathrm{~cm}^{3}$ of $1 \mathrm{~mol} \mathrm{dm}^{-3} \mathrm{KOH}_{\text {(aq) }}$ electrolyte, which was degassed by bubbling nitrogen for $1 \mathrm{~h}$ through the solution then maintained as oxygen-free by passing nitrogen through the cell. The working electrode was then immersed and cyclic voltammograms (CVs) collected at various scan rates. Specific capacitance was calculated as half the integral of the CV trace / (scan rate $\times$ width of the potential window $\times$ mass of manganese nitride).

The lithium- and sodium-battery performance was tested in two-electrode Swagelok cells. Lithium cells were prepared with lithium metal foil (Sigma-Aldrich) as the counter and pseudo reference electrode, and a separator consisting of two sheets of dried Whatman GF/D borosilicate glass fibre soaked in 6 drops of a commercial $1 \mathrm{~mol} \mathrm{dm}^{-3}$ LiPF $_{6}$ in ethylene carbonate/dimethyl carbonate (1:1) electrolyte (BASF). Sodium cells were assembled similarly using sodium metal foil (Sigma-Aldrich) and a $1 \mathrm{~mol} \mathrm{dm}^{-3} \mathrm{NaPF}_{6}$ in ethylene carbonate/diethyl carbonate (1:1) electrolyte. The latter electrolyte components were purified separately (solvents distilled from $\mathrm{BaO}$ and $\mathrm{NaPF}_{6}$ dried in 
vacuo at $120{ }^{\circ} \mathrm{C}$ ) before combining in the glove box. These cells were used to collect cyclic voltammograms or for galvanostatic cycling.

\section{Results and Discussion}

Reactions of $\mathrm{MnCl}_{2}$ and $\mathrm{LiNH}_{2}$ in benzene were carried out at various temperatures, and PXD patterns showed $\mathrm{Mn}_{3} \mathrm{~N}_{2}$ through the reaction temperature range $350-550{ }^{\circ} \mathrm{C}$, Fig. 1 . Methanol washing was effective at removal of the lithium chloride by-product and the products contain no other crystalline impurities, apart from some $\mathrm{Mn}_{2} \mathrm{~N}$ due to thermal decomposition of the $\mathrm{Mn}_{3} \mathrm{~N}_{2}$ at $550{ }^{\circ} \mathrm{C}$. Rietveld fitting of these patterns yielded good fits and lattice parameters close to the literature values for $\mathrm{Mn}_{3} \mathrm{~N}_{2}$, Table 1. Refinement of the $\mathrm{Mn}_{2} \mathrm{~N}$ phase fraction of the sample prepared at $550{ }^{\circ} \mathrm{C}$ showed it to be present at $10.4 \mathrm{wt} \%$.

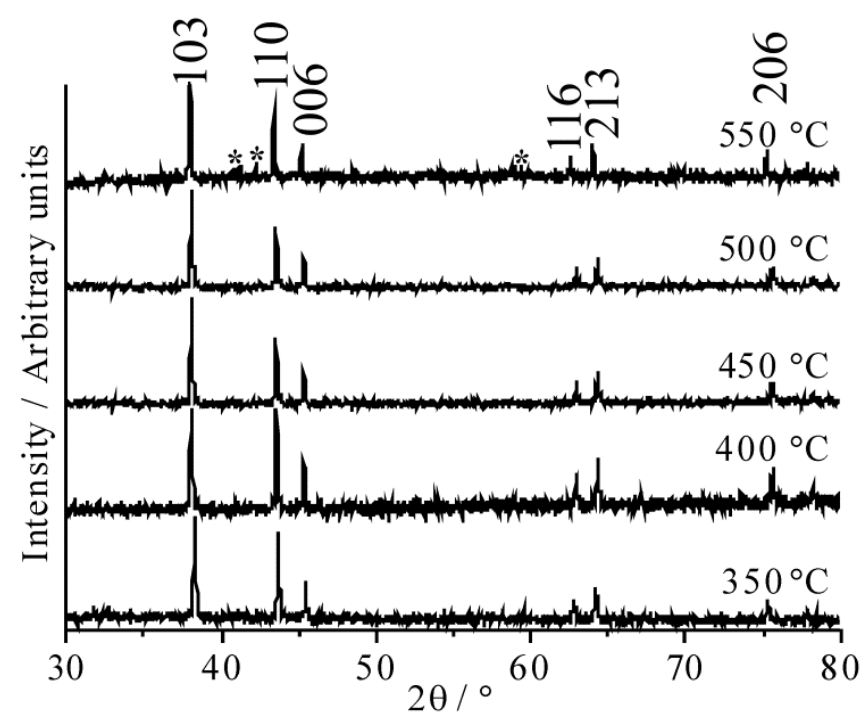

Fig. 1 PXD patterns of $\mathrm{Mn}_{3} \mathrm{~N}_{2}$ samples prepared under solvothermal conditions at various temperatures. Reflections due to $\mathrm{Mn}_{3} \mathrm{~N}_{2}$ are labelled with Miller indices and those due to $\mathrm{Mn}_{2} \mathrm{~N}$ at $550{ }^{\circ} \mathrm{C}$ labelled with asterisks.

Table 1 Rietveld fit parameters and compositions calculated from combustion analysis results for $\mathrm{Mn}_{3} \mathrm{~N}_{2}$ samples prepared by solvothermal synthesis then washed with methanol.

\begin{tabular}{|c|c|c|c|c|c|c|c|}
\hline $\begin{array}{l}\text { Temperature } \\
/{ }^{\circ} \mathrm{C}\end{array}$ & Phase & $a(\AA)$ & $b(\AA ̊)$ & $c(\AA)$ & $\begin{array}{l}R_{w p}, R_{p} \\
/ \%\end{array}$ & $\begin{array}{l}\text { Crystallite } \\
\text { size / nm }\end{array}$ & $\begin{array}{l}\text { Analysed } \\
\text { composition }\end{array}$ \\
\hline 350 & $\mathrm{Mn}_{3} \mathrm{~N}_{2}$ & $2.9733(3)$ & & $12.1258(12)$ & $4.6,3.6$ & 71 & $\mathrm{MnN}_{0.48} \mathrm{C}_{0.02} \mathrm{H}_{0.90}$ \\
\hline 400 & $\mathrm{Mn}_{3} \mathrm{~N}_{2}$ & $2.977(3)$ & & $12.1422(14)$ & $7.2,5.7$ & 53 & $\mathrm{MnN}_{0.48} \mathrm{C}_{0.02} \mathrm{H}_{0.84}$ \\
\hline 450 & $\mathrm{Mn}_{3} \mathrm{~N}_{2}$ & $2.977(2)$ & & $12.1417(10)$ & $5.4,4.7$ & 80 & $\mathrm{MnN}_{0.48} \mathrm{C}_{0.02} \mathrm{H}_{0.83}$ \\
\hline 500 & $\mathrm{Mn}_{3} \mathrm{~N}_{2}$ & $2.9754(14)$ & & $12.1341(7)$ & $4.8,3.8$ & 75 & $\mathrm{MnN}_{0.43} \mathrm{C}_{0.04} \mathrm{H}_{0.86}$ \\
\hline \multirow[t]{2}{*}{550} & $\mathrm{Mn}_{3} \mathrm{~N}_{2}$ & $2.9728(4)$ & & $12.1238(6)$ & $6.6,5.2$ & 87 & $\mathrm{MnN}_{0.33} \mathrm{C}_{0.32} \mathrm{H}_{1.08}$ \\
\hline & $\mathrm{Mn}_{2} \mathrm{~N}$ & $5.6609(2)$ & $5.0574(4)$ & $4.4449(7)$ & & 68 & \\
\hline
\end{tabular}

$\eta$ - $\mathrm{Mn}_{3} \mathrm{~N}_{2}$ model in $14 / \mathrm{mmm}$ from Hasegawa and Yagi, ${ }^{5}$ who reported $a=2.994(1)$ and $c=12.499(5) \AA . \zeta-\mathrm{Mn}_{2} \mathrm{~N}$ in Pbna from Mekata et $a l^{28}$ who reported $a=5.668, b=4.909$ and $c=4.537 \AA$. 
The solvothermal reaction of $\mathrm{MnCl}_{2}$ with $\mathrm{LiNH}_{2}$ presumably proceeds by metathesis reactions that substitute amide groups onto the manganese centres then condense with neighbouring manganese centres to yield nitride groups:

$$
\begin{aligned}
& \left.\mathrm{MnCl}_{2}+2 \mathrm{LiNH}_{2} \rightarrow \text { "Mn( } \mathrm{NH}_{2}\right)_{2} \text { " }+2 \mathrm{LiCl} \\
& \text { 3"Mn( } \left.\mathrm{NH}_{2}\right)_{2} \text { " } \rightarrow \mathrm{Mn}_{3} \mathrm{~N}_{2}+4 \mathrm{NH}_{3}
\end{aligned}
$$

These are unlikely to proceed in two distinct steps as shown, and amide groups are likely to condense as they form. Note that the manganese oxidation state is retained - often in ammonolysis reactions of amides the first product during pyrolysis retains the starting oxidation state, and when $\left[\mathrm{Mn}\left(\mathrm{N}\left(\mathrm{SiMe}_{3}\right)_{2}\right)_{2}\right]$ is reacted with ammonia a plateau in the TGA trace corresponding to manganese(II) was observed prior to nitrogen loss and crystallisation of $\mathrm{Mn}_{4} \mathrm{~N}^{4}{ }^{41}$ The advantage of solvothermal conditions is that the crystallisation step often occurs at lower temperature.

Combustion analysis, Table 1, showed nitrogen to be present in the range 7.93-10.80 wt\%, compared with a theoretical percentage of nitrogen in stoichiometric $\mathrm{Mn}_{3} \mathrm{~N}_{2}$ of $14.5 \%$. Hence all of these samples are nitrogen deficient. All samples contained carbon, with larger quantities found at the top of the synthesis temperature range where solvent decomposition was expected to be most significant. ${ }^{36}$ Hydrogen was also found throughout, presumably due to some unreacted amide or imide groups. This was confirmed by IR spectra showing a broad $v(\mathrm{NH})$ peak at $3480-3490 \mathrm{~cm}^{-1}$ and a weaker $\delta\left(\mathrm{NH}_{2}\right)$ at $1650-1700 \mathrm{~cm}^{-1}$, ${ }^{42}$ as well as a weak $\mathrm{v}(\mathrm{C}-\mathrm{H})$ at 2890 to $2980 \mathrm{~cm}^{-1}$. Nitrogen adsorption surface area measurements showed a gradual decrease in surface area, from $45 \mathrm{~m}^{2} \mathrm{~g}^{-1}$ at $350{ }^{\circ} \mathrm{C}$ to $47,33,32$ and $14 \mathrm{~m}^{2} \mathrm{~g}^{-1}$ at $400,450,500$ and $550{ }^{\circ} \mathrm{C}$ respectively. Samples prepared between 350 and $500{ }^{\circ} \mathrm{C}$ showed type IV isotherms with narrow hysteresis loops, with most of their pore volume concentrated into a single peak centred at $\sim 3.3-3.8 \mathrm{~nm}$. At $550{ }^{\circ} \mathrm{C}$ this distribution became much broader, with pore volume mainly observed over the size range $2-7 \mathrm{~nm}$.

TEM showed an increasing degree of aggregation as the synthesis temperature was raised, Fig. 2, but also an interesting hollow capsule morphology in samples prepared at $350{ }^{\circ} \mathrm{C}$, with lengths of $20-$ $120 \mathrm{~nm}$ and $\sim 20 \mathrm{~nm}$ diameter. Higher resolution images of the material obtained at $350{ }^{\circ} \mathrm{C}$ confirmed the hollow structures and showed that they are sometimes linked, and a selected area electron diffraction pattern of a region containing only this type of structure showed rings corresponding to the major diffraction peaks of $\mathrm{Mn}_{3} \mathrm{~N}_{2}$. These are broad due to overlap between more than one reflection and not all reflections are observed, presumably reflecting the partial alignment of the particles that are lying flat on the TEM grid. Occasional particles of turbostratic carbon were also observed and high resolution TEM showed fringes with a spacing consistent with a graphitic structure. 

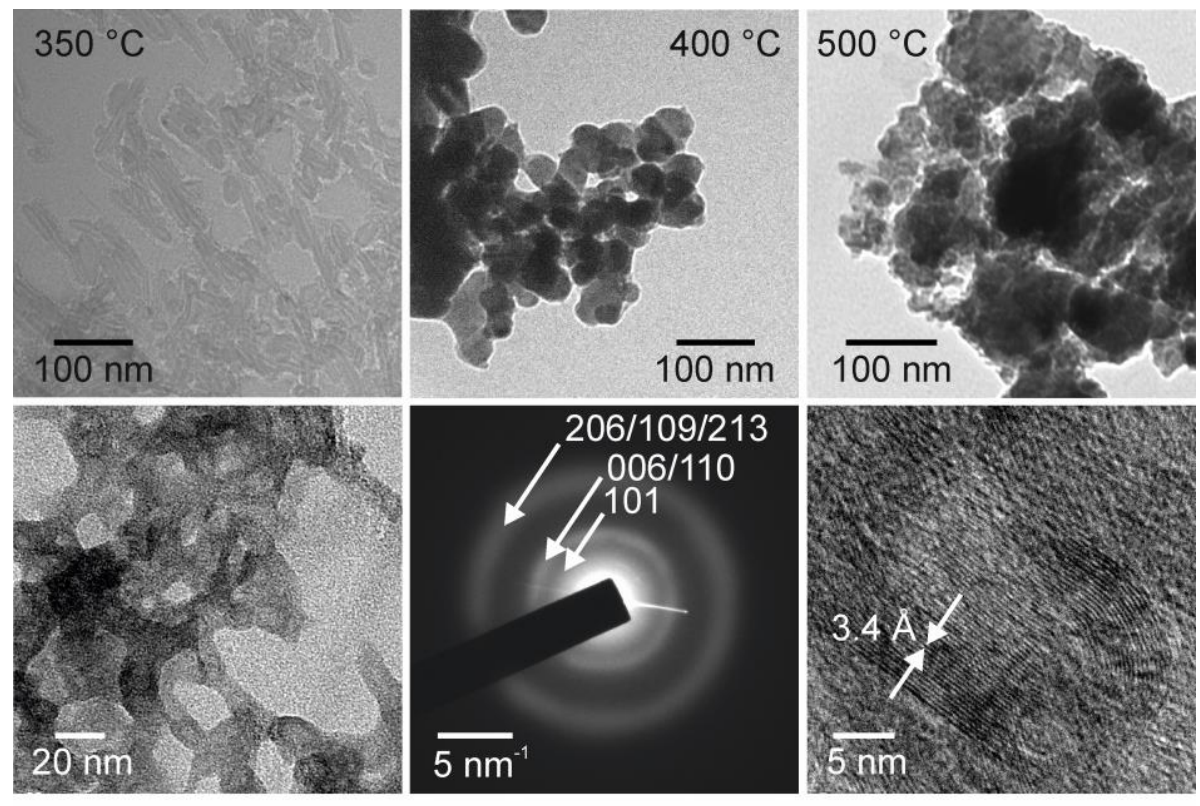

Fig. 2 TEM images of $\mathrm{Mn}_{3} \mathrm{~N}_{2}$ samples made at various temperatures as labelled (top), and higher resolution images and electron diffraction of a sample made at $350{ }^{\circ} \mathrm{C}$ (bottom) showing $\mathrm{Mn}_{3} \mathrm{~N}_{2}$ capsule structures (left), the selected area electron diffraction pattern of those capsules (middle) and lattice fringes from a carbon particle found in the sample (right).

Despite the low analysed carbon content the observation of graphitic structures in the TEM images of the samples prepared at $350{ }^{\circ} \mathrm{C}$ led to concerns about whether the capsule structures could be carbon-based, so Raman spectra were collected on samples prepared in the same way as those used for TEM. Specifically a suspension of the sample was prepared by ultrasonication, two drops ware placed on a TEM grid, then several drops of the same suspension on a glass microscope slide, then a final drop onto another TEM grid. The TEM grids were used to confirm that the sample morphology was consistent with other TEM samples. Once dry the sample on the glass slide was used to collect a Raman spectrum in the frequency range $2000-400 \mathrm{~cm}^{-1}$ at several different locations. A strong single peak was observed at $\sim 650 \mathrm{~cm}^{-1}$, consistent with $\mathrm{Mn}-\mathrm{N}$ and in a similar location to that observed in $\mathrm{TiN}$, MoN and $\mathrm{VN} .{ }^{43}$ The peak was broad at $350{ }^{\circ} \mathrm{C}$, became sharper at $400{ }^{\circ} \mathrm{C}$ and then grew in intensity as the crystallite size increased (Fig. 3). No Raman features associated with graphitic carbon were observed at $\sim 1350$ ( $D$ band) or $\sim 1580 \mathrm{~cm}^{-1}$ ( band). ${ }^{44}$

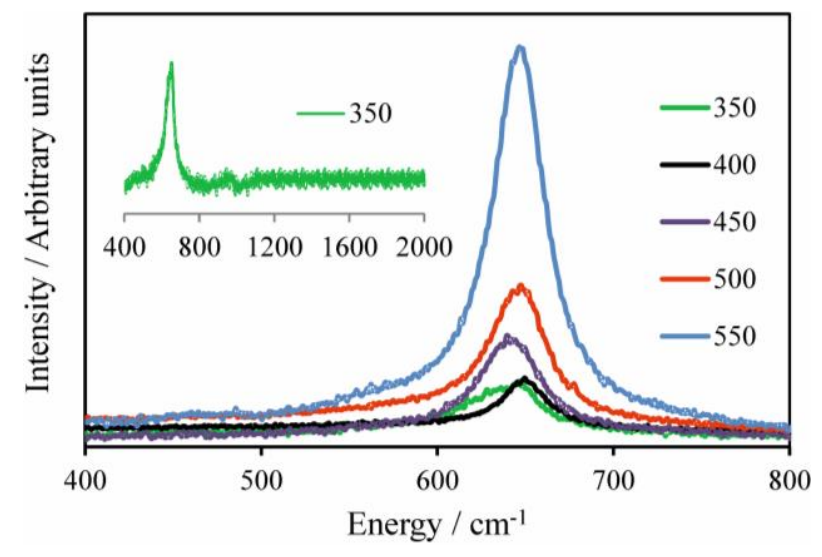

Fig. 3 Raman spectra of $\mathrm{Mn}_{3} \mathrm{~N}_{2}$ synthesised at temperatures as labelled. 


\section{Aqueous electrochemistry (supercapacitor performance)}

Metal nitrides have been tested as supercapacitor materials in various aqueous electrolytes including sulphuric acid or sodium sulphate solutions with molybdenum nitrides ${ }^{12}$ and potassium hydroxide solutions with TiN or VN. ${ }^{10,11} \mathrm{Mn}_{3} \mathrm{~N}_{2}$ was found to be highly unstable in acidic electrolytes so testing focussed on the electrochemistry in $\mathrm{KOH}$ solution. Titanium foils were used as the current collector as the foils themselves had very low capacitance $(\sim 0.1 \mathrm{~F})$ and did not develop any new features on extended cycling in the electrolytes used. Cyclic voltammograms were collected in a potential window of -0.6 to $+0.3 \mathrm{~V}$ vs $\mathrm{Hg} / \mathrm{HgO}$, beyond which limits continuously increasing reduction or oxidation features (respectively) were observed. With an uncoated titanium foil these features were observed at around -0.7 and $+0.4 \mathrm{~V}$, so the active material has a potential window only a little smaller than the solvent window.

Cyclic voltammograms (Fig. 4) were collected at various scan rates in $1 \mathrm{~mol} \mathrm{dm}^{-3}$ aqueous $\mathrm{KOH}$ solution. In all cases changes to the shape of the CV curves were observed over the first few cycles and their areas (charge passed, which is proportional to the capacitance) were reduced as a result of these changes. This effect was least prominent in samples prepared at higher temperatures, and samples prepared at $550^{\circ} \mathrm{C}$ showed only a small loss of area with cycling. The $\mathrm{CV}$ curves contained a number of oxidation and reduction peaks - at $100 \mathrm{mV} \mathrm{s}^{-1}$ scan rate only one reduction peak at around $-0.15 \mathrm{~V}$ could be clearly distinguished in most samples, with a further peak at $-0.40 \mathrm{~V}$ observable in samples prepared at $350{ }^{\circ} \mathrm{C}$. This latter sample also more clearly exhibits multiple oxidation features, with peaks at -0.2 and $0.1 \mathrm{~V}$, the $0.1 \mathrm{~V}$ peak appearing from its shape to be split and hence due to two process. At lower scan rates the presence of multiple oxidation and reduction processes becomes more obvious, with two main oxidation and reduction processes visible in each $\mathrm{CV}$. These features are present in the first cycle, when the potential was first swept positive from the open circuit value of $-0.32 \mathrm{~V}$, suggesting that $\mathrm{Mn}^{2+}$ in $\mathrm{Mn}_{3} \mathrm{~N}_{2}$ is oxidised to $\mathrm{Mn}^{4+}$ and reduced back to $\mathrm{Mn}^{2+}$. A previous study of $\mathrm{MnO}_{2}$ in $\left(\mathrm{NH}_{4}\right)_{2} \mathrm{SO}_{4(\text { aq) }}$ electrolyte showed CVs with no obvious peaks. ${ }^{45}$ 

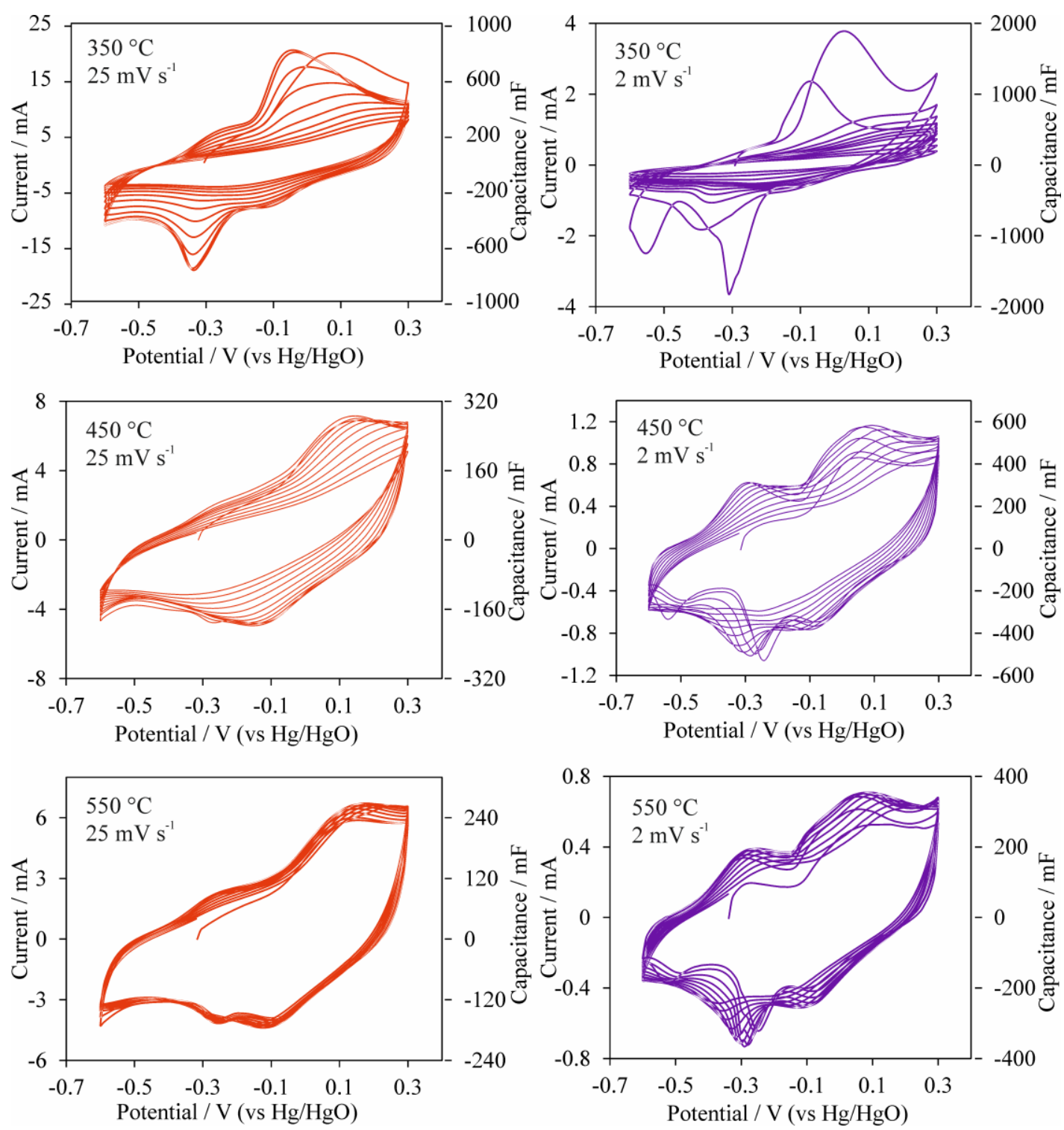

Fig. $4 \mathrm{CVs}$ of manganese nitride samples produced at 350,450 and $550{ }^{\circ} \mathrm{C}$, with scan rates of 25 or $2 \mathrm{mV} \mathrm{s}^{-1}$.

Capacitance can be calculated from the CV curves by dividing the charge passed by $(2 \times$ scan rate $\times$ potential window). The factor of 2 takes account of charging in both the positive and the negative direction in the curve. Variations in the capacitance for all samples and scan rates are shown in Fig. 5. $\mathrm{Mn}_{3} \mathrm{~N}_{2}$ samples obtained at $350{ }^{\circ} \mathrm{C}$ show the highest first cycle capacitances of $299 \mathrm{~F} \mathrm{~g}^{-1}$ at $2 \mathrm{mV} \mathrm{s}^{-1}$, or $130 \mathrm{~F} \mathrm{~g}^{-1}$ at $100 \mathrm{mV} \mathrm{s}^{-1}$. However this capacitance is observed to steadily reduce during cycling, reaching values of $91 \mathrm{~F} \mathrm{~g}^{-1}$ at $2 \mathrm{mV} \mathrm{s}^{-1}$ or $98 \mathrm{~F} \mathrm{~g}^{-1}$ at $100 \mathrm{mV} \mathrm{s}^{-1}$ after just 10 cycles. After 10 cycles the curves are flattened out and redox peaks are of small magnitude, suggesting that chemical changes at the surface of the particles are reducing the redox activity and that double layer formation, rather than redox processes, is becoming responsible for the bulk of the capacitance. The larger drop at slow rates can be attributed to the length of time in each cycle that the electrode spends under oxidising or reducing conditions (whichever is causing damage). Increasing the annealing temperature results in samples with lower capacitances due to the lower surface areas, and similar losses on cycling (Fig. 5). The exception is that at the highest synthesis temperature studied $\left(550^{\circ} \mathrm{C}\right.$ ), although the capacitances were lower in the first cycle $\left(123 \mathrm{~F} \mathrm{~g}^{-1}\right.$ at $2 \mathrm{mV} \mathrm{s}^{-1}$ or $66 \mathrm{~F} \mathrm{~g}^{-1}$ at $\left.100 \mathrm{mV} \mathrm{s}^{-1}\right)$ 
the drop in capacitance was proportionately less $\left(118 \mathrm{~F} \mathrm{~g}^{-1}\right.$ at $2 \mathrm{mV} \mathrm{s}^{-1}$ or $64 \mathrm{~F} \mathrm{~g}^{-1}$ at $100 \mathrm{mV} \mathrm{s}^{-1}$ in the $10^{\text {th }}$ cycle).
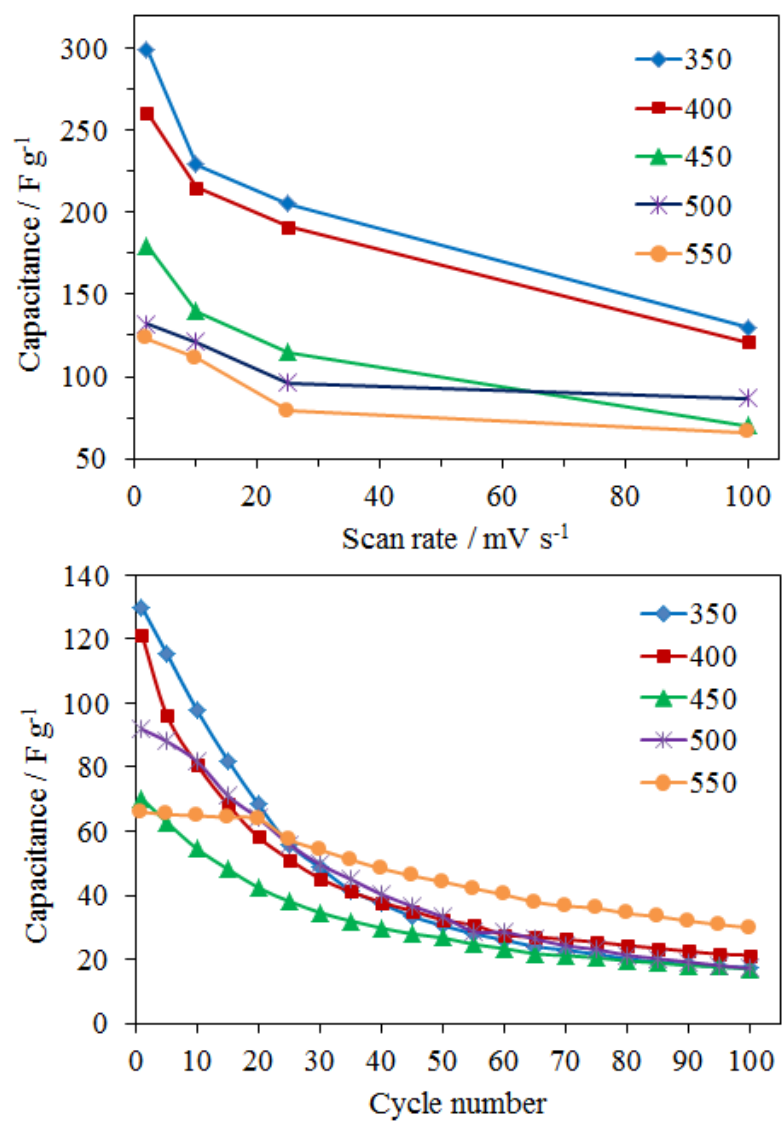

Fig. 5 Variation of first cycle specific capacitance of $\mathrm{Mn}_{3} \mathrm{~N}_{2}$ samples with scan rate and annealing temperature (top) and variation with cycle number when scanned at $100 \mathrm{mV} \mathrm{s}^{-1}$ (bottom).

\section{Electrochemistry in lithium and sodium electrolytes (battery performance)}

Our previous work using conversion reactions of metal nitrides in sodium cells has shown that performance is intimately linked with surface area, hence these studies focussed on samples produced at $350{ }^{\circ} \mathrm{C}$. A previous report shows thin $\mathrm{Mn}_{3} \mathrm{~N}_{2}$ films cycled vs lithium in a $\mathrm{Li}^{+}$-containing electrolyte to have a reversible capacity of $500 \mathrm{~mA} \mathrm{~h} \mathrm{~g}^{-1}$ or more, depending on the current, and good cycling capability. ${ }^{26}$ Hence initially our composite electrodes containing nanocrystalline $\mathrm{Mn}_{3} \mathrm{~N}_{2}$ were tested in lithium cells with a $1 \mathrm{~mol} \mathrm{dm}^{-3} \mathrm{LiPF}_{6}$ in EC/DMC electrolyte.

CVs of lithium half cells (Fig. 6) showed reduction features at 0.7 and $\sim 0 \mathrm{~V}$ vs Li in the first cycle, with the $0.7 \mathrm{~V}$ feature moving to $\sim 0.9 \mathrm{~V}$ in subsequent cycles and gradually losing intensity. Oxidation features were observed at 0.5 and $1.3 \mathrm{~V}$. Two features were also observed at slightly different potentials in thin films ${ }^{26}$ and support the assumption that $\mathrm{Mn}_{3} \mathrm{~N}_{2}$ is being reduced to manganese metal during cycling. Galvanostatic cycling at $200 \mathrm{~mA} \mathrm{~g}^{-1}$ (equivalent to $0.24 \mathrm{C}$ based on reduction to $\mathrm{Mn}$ and $\mathrm{Li}_{3} \mathrm{~N}$ with a theoretical capacity of $833 \mathrm{~mA} \mathrm{~h} \mathrm{~g}^{-1}$ ) resulted in multiple features and a larger than theoretical capacity during the first reduction, suggesting other processes including solid electrolyte interface (SEI) formation during this step, but then two oxidation features. The capacity then settled into high reversible values of around $600 \mathrm{~mA} \mathrm{~h} \mathrm{~g}^{-1}$ in the initial cycles, similar to that 
observed in thin films, ${ }^{26}$ but gradually reduced until the capacity was $340 \mathrm{~mA} \mathrm{~h} \mathrm{~g}{ }^{-1}$ after 50 cycles. During reduction almost all charge is passed in the potential region below $2 \mathrm{~V}$, but during oxidation (which is the discharge process in the context of a lithium-ion cell) the proportion of the charge passed in the potential region $0.001-2 \mathrm{~V}$ is around $57 \%$ in the first cycle, improving to $97 \%$ in the $50^{\text {th }}$.
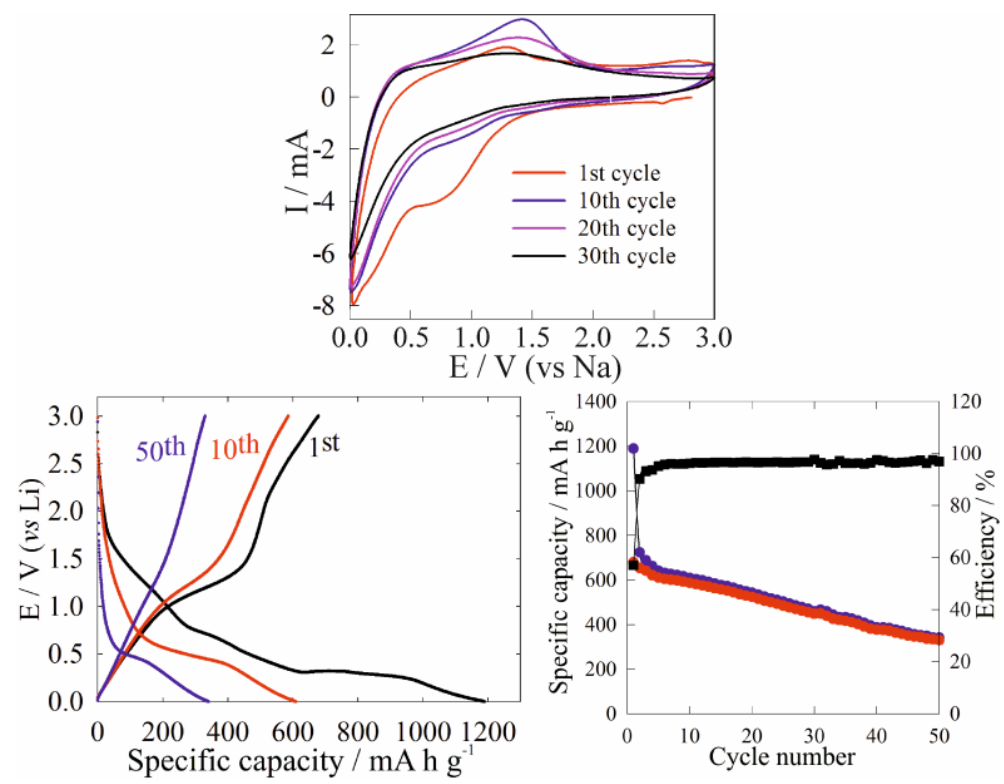

Fig. $6 \mathrm{CV}\left(10 \mathrm{mV} \mathrm{s}^{-1}\right)$ in a lithium half cell (1M LiPF 6 in EC/DMC electrolyte), of an electrode prepared with $\mathrm{Mn}_{3} \mathrm{~N}_{2}$ made at $350{ }^{\circ} \mathrm{C}$ (top), voltage profile during galvanostatic reduction and oxidation at $200 \mathrm{~mA} \mathrm{~g}^{-1}$ (bottom left) and specific capacity vs cycle number at $200 \mathrm{~mA} \mathrm{~g}^{-1}$ (bottom right). In the latter plot reduction capacity is marked in blue, oxidation capacity in red and Coulombic efficiency in black.

The lower current level of development level in sodium battery negative electrodes compared with those for lithium cells ${ }^{25}$ makes new materials particularly interesting in this application. The CV in a sodium half cell showed multiple reduction features in the first cycle, but a much simpler oxidation profile and simple reduction profiles in all subsequent cycles. Galvanostatic reduction at $200 \mathrm{~mA} \mathrm{~g}^{-1}$ (0.24C) showed a first cycle reduction capacity of $486 \mathrm{~mA} \mathrm{~h} \mathrm{~g}^{-1}$ with multiple features in the potential trace, and as with lithium the first cycle oxidation capacity $\left(1189 \mathrm{~mA} \mathrm{~h} \mathrm{~g}^{-1}\right)$, and subsequent reduction and oxidation capacities ( 87 and $81 \mathrm{~mA} \mathrm{~h} \mathrm{~g}^{-1}$ respectively in the $10^{\text {th }} \mathrm{cycle}$, and 78 and 77 $\mathrm{mA} \mathrm{h} \mathrm{g}^{-1}$ in the $50^{\text {th }}$ ), were smaller. Notably the cycling behaviour is good, only $33 \%$ of the reduction capacity and $9 \%$ of the oxidation capacity is lost between the $2^{\text {nd }}$ and $50^{\text {th }}$ cycle. During reduction virtually all the charge is passed in the potential region below $2 \mathrm{~V}$, whereas during oxidation $68 \%$ is passed below $2 \mathrm{~V}$ (based on the $50^{\text {th }}$ cycle). Reducing the current to $50 \mathrm{~mA} \mathrm{~g}^{-1}(0.06 \mathrm{C})$ a larger first reduction capacity of $623 \mathrm{~mA} \mathrm{~h} \mathrm{~g}^{-1}$ was observed, with $156 \mathrm{~mA} \mathrm{~h} \mathrm{~g}^{-1}$ recovered in the first oxidation. The higher values also persisted during cycling, which again showed good stability, e.g. the reduction capacity was $142 \mathrm{~mA} \mathrm{~h} \mathrm{~g}^{-1}$ in the $10^{\text {th }}$ cycle and $127 \mathrm{~mA} \mathrm{~h} \mathrm{~g}^{-1}$ in the $50^{\text {th }}$ cycle. 

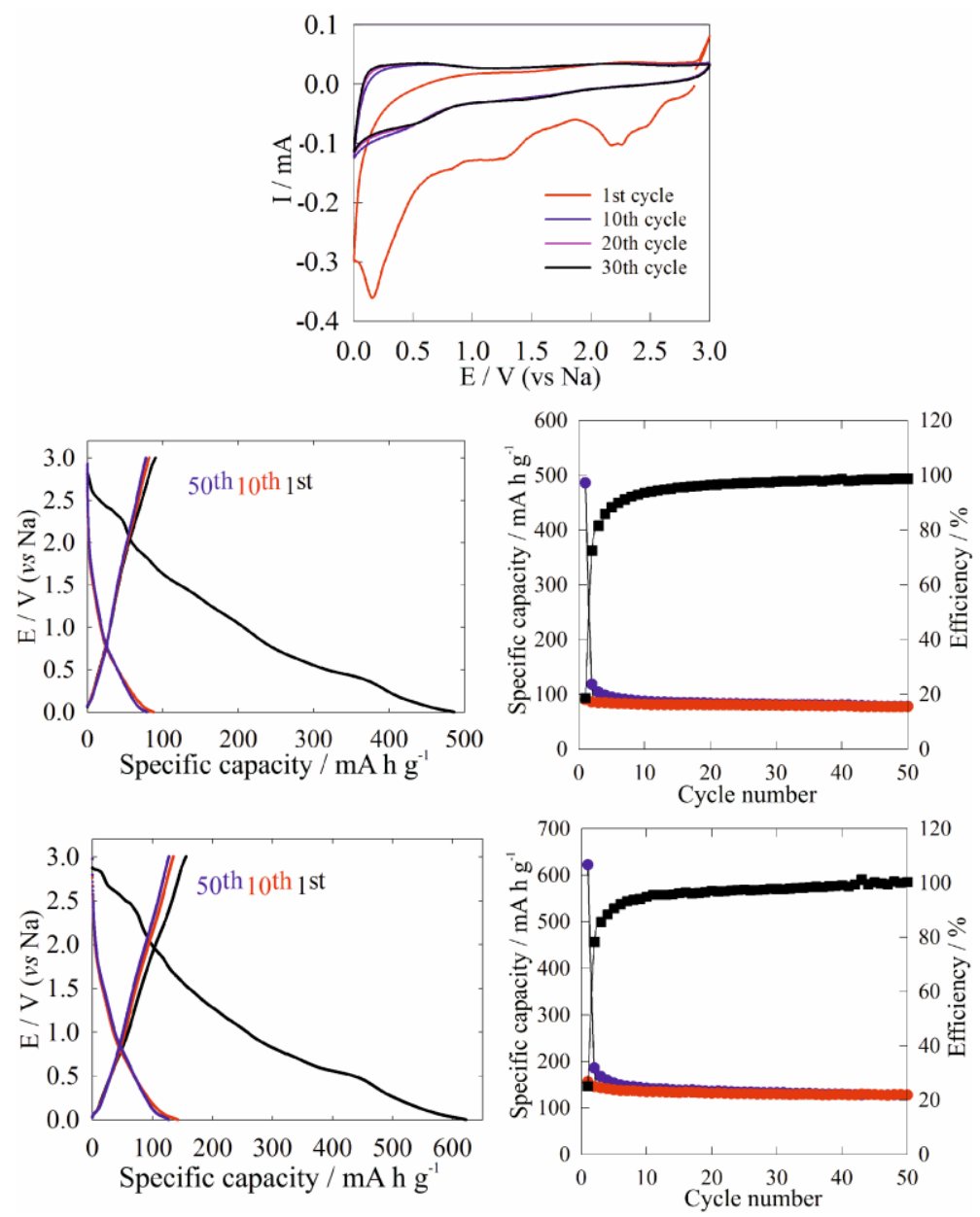

Fig. $7 \mathrm{CV}\left(10 \mathrm{mV} \mathrm{s}^{-1}\right)$ in a sodium half cell $\left(1 \mathrm{M} \mathrm{NaPF}_{6}\right.$ in EC/DEC) of an electrode prepared with $\mathrm{Mn}_{3} \mathrm{~N}_{2}$ made at $350{ }^{\circ} \mathrm{C}$ (top), and voltage profile during galvanostatic reduction and oxidation (left) and specific capacity vs cycle number (right) at $200 \mathrm{~mA} \mathrm{~g}^{-1}$ (centre) and $50 \mathrm{~mA} \mathrm{~g}^{-1}$ (bottom). In the capacity vs cycle number plots reduction capacity is marked in blue, oxidation capacity in red and Coulombic efficiency in black.

\section{Conclusions}

Solvothermal synthesis from $\mathrm{MnCl}_{2}$ and $\mathrm{LiNH}_{2}$ is an effective route to make nanocrystalline $\mathrm{Mn}_{3} \mathrm{~N}_{2}$, with unusual nanocapsule morphologies at $350{ }^{\circ} \mathrm{C}$ synthesis temperature giving way to loose aggregates of nanoparticles at higher temperature until at $550{ }^{\circ} \mathrm{C}$ some decomposition to $\mathrm{Mn}_{2} \mathrm{~N}$ is introduced. These particles can store charge in aqueous potassium hydroxide solutions with capacities observed over $100 \mathrm{~F} \mathrm{~g}^{-1}$ at low scan rates, but were subject to significant capacity fade on cycling. In lithium half cells good initial capacities were observed but these were also subject to fading during cycling. Performance in sodium half cells was much more competitive, although this is partly due to the lower general development level in these systems. At charge/discharge rates equivalent to $6 \%$ of the theoretical capacity per hour based on reduction to manganese metal, good cycling behaviour, high Coulombic efficiency and $127 \mathrm{~mA} \mathrm{~h} \mathrm{~g}^{-1}$ capacity after 50 cycles were observed in such cells. 


\section{Acknowledgements}

The authors thank Victor Costa-Bassetto for Raman support and Dr Shuncai Wang for assisting in collection of the high resolution TEM images. SIUS was supported by a University of Southampton PG scholarship.

\section{References}

${ }^{1}$ C. Guillaud and J. Wyart, Rev. Metall., 1948, 45, 271-276.

${ }^{2}$ A. Leineweber, H. Jacobs and W. Kockelmann, J. Alloys Cmpds., 2004, 368, 229-247.

${ }^{3}$ M. Aoki, H. Yamane, M. Shimada and T. Kajiwara, Mater. Res. Bull., 2004, 39, 827-832.

${ }^{4}$ G. Kreiner and H. Jacobs, J. Alloys Cmpds., 1992, 183, 345-362.

${ }^{5}$ M. Hasegawa and T. Yagi, J. Alloys Cmpds., 2005, 403, 131-142.

${ }^{6}$ K. Suzuki, T. Kaneko, H. Yoshida, Y. Obi, H. Fujimori and H. Morita, J. Alloys Cmpds., 2000, 306, 66-71.

${ }^{7}$ A. Leineweber, R. Niewa, H. Jacobs and W. Kockelmann, J. Mater. Chem., 2000, 10, 2827-2834.

${ }^{8}$ W. J. Takei, R. R. Heikes and G. Shirane, Phys. Rev., 1962, 125, 1893-1897.

${ }^{9}$ S. Dong, X. Chen, X. Zhang and G. Cui, Coord. Chem. Rev., 2013, 257, 1946-1956.

${ }^{10}$ R. A. Janes, M. Aldissi and R. B. Kaner, Chem. Mater., 2003, 15, 4431-4435.

${ }^{11}$ D. Choi, G. E. Blomgren and P. N. Kumta, Adv. Mater., 2006, 18, 1178-1182.

12 S. I. U. Shah, A. L. Hector and J. R. Owen, J. Power Sources, 2014, 266, 456-463.

${ }^{13}$ D. Yang, Application of nanocomposites for supercapacitors: characteristics and properties, chapter 12 in Nanocomposites - new trends and developments, F. Ebrahimi (Ed), Intech, 2012 (DOI:10.5772/50409).

${ }^{14}$ M. Toupin, T. Brousse and D. Bélanger, Chem. Mater., 2004, 16, 3184-3190.

${ }^{15}$ A. J. Roberts and R. C. T. Slade, J. Mater. Chem., 2010, 20, 3221-3226.

${ }^{16}$ J.Cabana, L. Monconduit, D. Larcher and M. R. Palacín, Adv. Mater., 2010, 22, E170-E192.

${ }_{17}$ Z. W. Fu, Y. Wang, X. L. Yue, S. L. Zhao and Q. Z. Qin, J. Phys. Chem. B, 2004, 108, 2236-2244; Q. Sun and Z. W. Fu, Electrochem. Sol. St. Lett., 2007, 10, A189-A193; Q. Sun and Z. W. Fu, Electrochem. Sol. St. Lett., 2008, 11, A233-A237; Q. Sun, Z. W. Fu, Electrochim. Acta, 2008, 54, 403-409.

${ }^{18}$ Y. Wang, W. Y. Liu and Z. W. Fu, Acta Phys. Chim. Sin., 2006, 22, 65-70.

${ }^{19}$ Y. Wang, Z. W. Fu, X. L. Yue and Q. Z. Qin, J. Electrochem. Soc., 2004, 151, E162-E167.

${ }^{20}$ B. Das, M. V. Reddy, P. Malar, T. Osipowicz, G. V. S. Rao and B. V. R. Chowdari, Sol. St. Ionics, 2009, 180, 1061-1068.

${ }^{21}$ F. Gillot, J. Oro-Sole and M. R. Palacín, J. Mater. Chem., 2011, 21, 9997-10002.

22 J. Ma, L. Yu and Z. W. Fu, Electrochim. Acta, 2006, 51, 4802-4814; N. Pereira, L. Dupont, J. M. Tarascon, L. C. Klein and G. G. Amatucci, J. Electrochem. Soc., 2003, 159, A1273-A1280.

${ }^{23}$ X. Li, M. M. Hasan, A. L. Hector and J. R. Owen, J. Mater. Chem. A, 2013, 1, 6441-6445.

${ }^{24}$ X. Li, A. L. Hector and J. R. Owen, J. Phys. Chem. C, in press (DOI:10.1021/jp509385w).

${ }^{25}$ V. Palomares, P. Serras, I. Villaluenga, K. B. Hueso, J. Carretero-González and T. Rojo, Energy Environ. Sci., 2012, 5, 5884-5901.

${ }^{26}$ Q. Sun and Z.-W. Fu, Appl. Surf. Sci., 2012, 258, 3197-3201.

${ }^{27}$ K. Zhang, X. Han, Z. Hu, X. Zhang, Z. Tao and J. Chen, Chem. Soc. Rev., in press (DOI:10.1039/c4cs00218k).

28 M. Mekata, J. Haruna and H. Takaki, J. Phys. Soc. Jpn., 1968, 25, 234-238.

${ }^{29}$ W. J. Feng, N. K. Sun, J. Du, Q. Zhang, X. G. Liu, Y. F. Deng and Z. D. Zhang, Sol. St. Commun., 2008, 148, 199202.

${ }^{30}$ A. L. Hector and I. P. Parkin, Polyhedron, 1995, 14, 913-917.

${ }^{31}$ A. L. Hector and I. P. Parkin, Chem. Mater., 1996, 7, 1728-1733.

32 J. C. Fitzmaurice, A. L. Hector and I. P. Parkin, J. Chem. Soc., Dalton Trans., 1993, 2435-2438.

${ }^{33}$ G. Kreiner and H. Jacobs, J. Alloys Cmpds., 1992, 183, 345-362.

${ }^{34}$ I. P. Parkin and A. T. Rowley, J. Mater. Chem., 1995, 5, 909-912.

35 P. Chirico, A. L. Hector and B. Mazumder, Dalton Trans., 2010, 39, 6092-6097; B. Mazumder and A. L. Hector, J. Mater. Chem., 2008, 18, 1392-1398; P. Chirico and A. L. Hector, Z. Naturforsch., 2010, 65b, 1051-1057.

${ }^{36}$ B. Mazumder, P. Chirico and A. L. Hector, Inorg. Chem., 2008, 47, 9684-9690.

37 J. Choi and E. G. Gillan, Inorg. Chem., 2009, 48, 4470-4477.

${ }^{38}$ A. C. Larson, R. B. Von Dreele, Generalized Structure Analysis System (GSAS), Los Alamos National Laboratory Report LAUR (2004) 86-748; B. H. Toby, J. Appl. Cryst., 2001, 34, 210-213. 
${ }^{39}$ Inorganic Crystal Structure Database (ICSD, Fiz Karlsruhe) accessed via the EPSRC-funded National Chemical Database Service hosted by the Royal Society of Chemistry.

${ }^{40}$ R. B. Von Dreele, A. C. Larson, GSAS manual, LANSCE MS-H805, Los Alamos National Laboratory, NM87545 (2000).

${ }^{41}$ D. V. Baxter, M. H. Chisholm, G. J. Gama, V. F. DiStasi, A. L. Hector and I. P. Parkin, Chem. Mater., 1996, 8, 1222-1228.

${ }^{42}$ K. Nakamoto, Infrared and Raman Spectra of Inorganic and Organic Compounds, 3rd ed.; J. Wiley, New York, 1978.

${ }^{43}$ O. Shebanova, E. Soignard and P. F. McMillan, High Press. Res., 2006, 26, 87-97.

${ }^{44}$ M. Fang, K. Wang, H. Lu, Y. Yang and S. Nutt, J. Mater. Chem., 2009, 19, 7098-7105; D. Yuan, X. Yuan, W. Zou, F. Zeng, X. Huang and X. Zhou, J. Mater. Chem., 2012, 22, 17820-17826.

45 A. J. Roberts and R. C.T. Slade, Electrochim. Acta, 2010, 55, 7460-7469. 